\title{
Comparative behavior of wheat and barley associated with field release and grain weight determination
}

\author{
Santiago Alvarez Prado ${ }^{\mathrm{a}, *}$, José M. Gallardo ${ }^{\mathrm{a}}$, Román A. Serrago ${ }^{\mathrm{a}, \mathrm{b}}$, Betina C. Kruk ${ }^{\mathrm{a}}$, Daniel J. Miralles ${ }^{\mathrm{a}, \mathrm{b}}$ \\ a Cátedra de Cerealicultura, Departamento de Producción Vegetal, Universidad de Buenos Aires, Av San Martín 4453 (C 1417 DSE), Ciudad de Buenos Aires, Argentina \\ ${ }^{\mathrm{b}}$ IFEVA and CONICET, Av. San Martín 4453 (C 1417 DSE), Ciudad de Buenos Aires, Argentina
}

\section{A R T I C L E I N F O}

\section{Article history:}

Received 13 April 2012

Received in revised form

31 December 2012

Accepted 31 December 2012

\section{Keywords:}

Flowering time

Grain-filling duration

Maximum water content

Moisture concentration

Source:sink ratio

\begin{abstract}
A B S T R A C T
Double-cropping using the wheat-soybean sequence is a common practice in Argentina to promote the intensification of crops within rotations. However, the late release of the fields by a delayed harvest time in wheat determines soybean yield penalizations. In this context, barley could represent a better option than wheat preceding soybean in the crop rotation since there is some evidence that finishes its cycle earlier than wheat. However, it is not clear which period of barley shortens crop cycle allowing an earlier field release than wheat. The objectives of this study were to compare wheat and barley in terms of (i) field release and (ii) grain weight determination through the analysis of their physiological mechanisms. Field experiments during two consecutive growing seasons testing five different environments (three sowing dates in 2007 and two in 2008) were carried out to analyze the duration of different ontogenic periods and the attributes (dry matter and water dynamics) determining grain weight during the grainfilling period in wheat and barley. Early flowering time was the main cause of the early field release by barley as the grain filling and drying period were similar in both species. A strong relationship was found between dry matter and water dynamics in both species. Barley reached a higher maximum water content than wheat and also achieved physiological maturity with higher moisture concentration than wheat (48\% and 39\%, respectively). Barley showed a slight increase in grain weight, respect to wheat, due to a source:sink ratio enhancement ( $4 \%$ and $9 \%$ for wheat and barley, respectively). These data show an opposite response to that of Mediterranean, Australian and UK environments, where barley was under stronger sink limitation than wheat during the grain-filling period.
\end{abstract}

(c) 2013 Elsevier B.V. All rights reserved.

\section{Introduction}

Wheat/soybean double-cropping is a common farming system where soybean is frequently sown immediately after wheat harvest, too late for maximizing soybean yield. In the Argentine Rolling Pampas, optimum sowing dates for soybeans range from early to mid-November (Andrade, 1995), 1.5-2 months earlier than wheat harvest. Calviño et al. (2003) quantified soybean yield reductions of $56 \mathrm{~kg} \mathrm{ha}^{-1}$ per day of sowing delay, highlighting the importance of advancing the winter crop harvest in this double-cropping system. Barley could therefore be better than wheat for this system as there is evidence that it matures earlier (Fischer and Wood, 1979; LópezCastañeda and Richards, 1994; Cossani et al., 2009, 2011). This could be ascribed to differences in (i) flowering time, (ii) grain-filling duration and/or (iii) the grain-drying period comprised from physiological maturity to the time grains reach the commercial moisture

\footnotetext{
* Corresponding author. Present address: Departamento de Producción Vegetal, Facultad de Ciencias Agrarias, Universidad Nacional de Rosario, S2125ZAA Zavalla, Santa Fe, Argentina. Tel.: +54 03414970080.

E-mail address: saprado@unr.edu.ar(S. Alvarez Prado).
}

values (14\%). Literature showed that flowering time is generally earlier in barley than in wheat (Fischer and Wood, 1979; Miralles and Richards, 2000; Cossani et al., 2009, 2011). For the grain-filling period, the scenario is less certain: there are studies where barley grain filling was sometimes shorter than (López-Castañeda and Richards, 1994; Ugarte et al., 2007), or similar to (Fischer and Wood, 1979; Lingle and Chevalier, 1985; Ugarte et al., 2007) that of wheat. As far as we know, there is little information concerning differences between wheat and barley in the length of the period between physiological and commercial maturity. As harvesting the winter cereals soon after physiological maturity is unfeasible, due to high costs of drying grains, reducing the duration from physiological to commercial maturity is of great importance to farmers. Thus, one aim of this study was to assess whether the differences between wheat and barley in time to commercial maturity were restricted to their differences in time to flowering or whether barley has also a shorter grain filling duration and/or a shorter drying period up to commercial maturity than wheat.

Grain water relations are useful tools for understanding grainfilling patterns (Schnyder and Baum, 1992; Borrás and Westgate, 2006). Developing grains accumulate more water than reserves immediately after flowering until water content is maximized 
relatively early in the grain filling period and remains stable during a period of time (known as "hydric plateau"). Once the hydric plateau is finished, grains start to lose water until harvest moisture is reached. The water loss rate during grain filling is negatively associated with the duration of grain filling (Gambín et al., 2007). As grain moisture concentration at physiological maturity seems similar for wheat (38\%; Calderini et al., 2000) and barley (40\%; Bingham et al., 2007b), differences in grain-filling duration would mainly depend on grain water loss. Although there is information available on grain water dynamics in wheat and barley (Schnyder and Baum, 1992; Calderini et al., 2000; Savin et al., 1997; Bingham et al., 2007b) there is virtually no comparison on these dynamics between these species growing simultaneously under different environments. Grain growth could be considered as controlled by either the supply of photo-assimilates (source limitation) or the capacity of the grains to accumulate available carbohydrates (sink limitation). Numerous experiments have been reported in which the supply of assimilate per grain was modified, suggesting a sink limitation for both, wheat and barley, and sometimes a co-limitation in wheat (Slafer and Savin, 1994; Miralles and Slafer, 1995; Dreccer et al., 1997; Kruk et al., 1997; Bingham et al., 2007a; Serrago et al., 2011). However, under relatively dry environments, grain filling appears to be under stronger sink limitation in barley than in wheat (Josephides, 1993; López-Castañeda and Richards, 1994). For UK conditions, Bingham et al. (2009) reached similar conclusions. On the other hand, for Argentine conditions, barley appears to be more responsive than wheat when enhancing the assimilate supply per grain (Arisnabarreta, unpublished data). There is no published information regarding source:sink manipulations comparing wheat and barley growing together under Argentine conditions. Thus, the second objective of the present work was to compare wheat and barley in terms of grain weight determination.

\section{Materials and methods}

\subsection{General description and treatments}

Field experiments were carried out during two consecutive growing seasons (2007 and 2008) in the experimental field of the Department of Plant Production, University of Buenos Aires, Argentina $\left(34^{\circ} 35^{\prime} \mathrm{S}, 58^{\circ} 29^{\prime} \mathrm{W}\right)$. The soil was a silty clay loam, classified as Vertic Argiudoll.

Treatments were a combination of two commercial cultivars of wheat (Klein Chaja and Cronox) and two-row barley (Quilmes Ayelen and Scarlett) sown simultaneously at four (2007) and two (2008) different sowing dates. In 2008, a source:sink treatment was also imposed within each genotype and sowing date.

The selected genotypes are the best alternative of each species for the double-cropping system in Argentina. In barley, the two genotypes selected corresponded to (i) one of the earliest flowering commercial cultivars (Q. Ayelen) and (ii) the most widely used by farmers (Scarlett), with slightly later flowering than Q. Ayelen. Wheat genotypes selected were K. Chaja, the earliest flowering among commercial cultivars, and Cronox, one of the most widely grown by farmers, with a slightly later flowering than K. Chaja. Both species were hand-sown on 21 May, 5 July, 23 July and 17 August in 2007 and 6 June and 13 August in 2008 at a density of 330 seeds $\mathrm{m}^{-2}$. The source:sink ratios were modified by manipulating the number of spikelets per spike from main shoots. For this purpose, seven days after flowering, 50 main shoots were randomly selected and tagged in each sub-plot. In half of these shoots, spikes were trimmed removing by hand all the spikelets from one side of the spike (see Miralles and Slafer, 1995), reducing c. 50\% of the sinks, while the other half spikes were left unaltered as controls.
Treatments were arranged in a split-plot design, with sowing dates assigned to main-plots and genotypes to sub-plots. Source:sink treatments imposed in 2008 were assigned to sub-subplots. Main plots were randomized in three blocks in all sowings but in those of 5 July and 17 August 2007 in which there were two blocks. Each sub-plot (genotypes) consisted of seven rows $15 \mathrm{~cm}$ apart and $2 \mathrm{~m}$ long. As size of the plots was small, the sowing was made using a special procedure maximizing uniformity as described by Estrada-Campuzano et al. (2012). Briefly, seeds were firstly evenly distributed in strips of sticky-tape of biodegradable paper of the same row length. Soil was refined to minimize interference with seedling emergence and individual furrows were manually opened where the strips of tape were placed, covered with refined soil, lightly compacted by hand, and wetted to ensure prompt imbibition.

All the experiments were irrigated throughout the growing season to avoid water stress, and fertilized at sowing, at the beginning of tillering and first detectable node in main shoots. Pests and diseases were prevented or controlled by spraying recommended fungicides and insecticides, and weeds were periodically removed by hand. To prevent lodging, structures with nets were installed during tillering, and plants grew through these nets from then onwards.

\subsection{Sampling and measurements}

Flowering time was recorded when $50 \%$ of the spikes exposed anthers in the middle part of the spike in wheat. In barley, flowering time was determined by observing floret stages inside the spikelets because floret fecundation normally occurs before anther emergence and usually anther emergence cannot be observed. When $50 \%$ of the selected spikes showed fertile florets according with Waddington et al. (1983), we considered that the plot had reached the flowering stage. This stage generally coincided in barley with visible awns over the flag leaf sheath.

Three spikes per experimental unit were sampled twice or thrice a week from flowering to after commercial maturity, immediately enclosed in a hermetic plastic bag, and transported to the laboratory. In 2007, proximal grains from central spikelets (C1) in wheat and grains from central spikelets in barley were separated from the spikes in a humidified box to prevent moisture loses during sampling. During 2008, wheat grains closest to the rachis (grain 1 ), the second (grain 2) and the third (grain 3) were sampled from central spikelets, referred to as $\mathrm{C} 1, \mathrm{C} 2$ and $\mathrm{C} 3$, respectively, as well as grains 1 and 2 from the apical spikelets (A1 and A2). In barley, grains were sampled from central (C) and apical (A) spikelets. Fresh weight was determined immediately and dry weight was measured after drying the grains in a forced-air oven at $70^{\circ} \mathrm{C}$ for at least $72 \mathrm{~h}$.

\subsection{Analyses}

Water content was calculated as the difference between grain fresh weight $\left(F_{\mathrm{W}}\right)$ and grain dry weight $\left(D_{\mathrm{W}}\right)$. A tri-linear model with plateau was fitted for the relationship between water content and thermal time:

$$
\begin{aligned}
& W_{\mathrm{C}}=a+b x, \quad \text { if } x \leq c ; \quad W_{\mathrm{C}}=a+b c, \quad \text { if } x>c<e ; \\
& W_{\mathrm{C}}=a+b c+d(x-e) x, \quad \text { if } x \geq e
\end{aligned}
$$

where $x$ is thermal time, $W_{C}$ is water content, $a$ the $Y$-intercept, $b$ the water accumulation rate $\left(\mathrm{mg}\left[{ }^{\circ} \mathrm{Cd}\right]^{-1}\right), c$ the beginning of the hydric plateau $\left({ }^{\circ} \mathrm{Cd}\right), d$ the water loss rate $\left(\mathrm{mg}\left[{ }^{\circ} \mathrm{Cd}\right]^{-1}\right)$ and $e$ the end of the hydric plateau $\left({ }^{\circ} \mathrm{Cd}\right)$. The hydric plateau duration was calculated as $(e-c)$. The value of water content during the hydric plateau was considered as the maximum water content. 
Moisture concentration $\left(M_{\mathrm{C}}\right)$ was calculated as the ratio between $W_{C}$ and grain fresh weight.

A bilinear model with a plateau was used to fit the relationship between relative grain dry weight (dry weight at any time as a percentage of final grain weight) and $M_{C}$ :

$\mathrm{RGD}_{\mathrm{W}}=a+b, \quad$ if $\quad x \geq c ; \quad \mathrm{RGD}_{\mathrm{W}}=a+b c, \quad$ if $x<c$

where $\mathrm{RGD}_{\mathrm{W}}$ is the relative grain dry weight; $a$ the $Y$-intercept; $b$ the slope; $c$ is the breakpoint between the two lines representing $M_{\mathrm{C}}$ at physiological maturity.

A tri-linear model, similar to that described for $W_{C}$ calculation, was used to relate the relative water content ( $W_{\mathrm{C}}$ at any time as a percentage of maximum $W_{\mathrm{C}} ; \% W_{\mathrm{C}}$ ) and $M_{\mathrm{C}}$.

The drying rate $\left(\mathrm{g}[\mathrm{kg}]^{-1} \mathrm{~d}^{-1}\right)$ was determined for grains from central positions in wheat and barley by fitting a simple regression model to the relationship between moisture concentration and days from physiological maturity to commercial maturity $\left(M_{\mathrm{C}}=14 \%\right)$.

To analyze species, genotypes, sowing dates and their interactions effects, a general linear model with nested effects (genotype nested inside species and blocks nested inside sowing dates) was used. PROC GLM from SAS (SAS Institute Inc., Cary, NC, USA), was also used to test the effects of genotypes, sowing dates, spikelet positions, grain positions within the spikelets and their interactions using the environments (sowing dates) as random effects.

\section{Results}

\subsection{Timing of field release}

Averaging across environments flowering time was 5 days earlier in barley than in wheat, but the magnitude of this difference varied between sowings (Table 1). Duration of the grain-filling period showed differences between species which, even though significant $(p<0.001)$, were lower than those for time to flowering (Table 1). Averaging, across sowings barley grain-filling period was 3 days shorter than that of wheat. After physiological maturity, drying down was faster in wheat than in barley $(p<0.001)$ in all the environments (Table 1 ). But as the magnitude of this difference was small, barley released the field in average 5 days earlier than wheat. Although the interaction with sowing dates was significant, in all cases barley released the field earlier than wheat (Table 1).

\subsection{Dynamic of grain water content}

Considering all genotypes $\times$ sowing dates combination, barley showed a significantly higher moisture concentration at physiological maturity ( $48 \pm 0.6 \%$ ) than wheat ( $39 \pm 0.6 \%$; Table 2 and Fig. 1 ). When the relative grain weight of both cultivars under all environments was plotted against grain moisture concentration, the rate of relative grain dry weight increase per unit of decreasing grain moisture concentration during the effective grain-filling period, was significantly higher in barley $\left(3.38 \pm 0.11 \%_{\text {RGDW }}\left[\%_{\mathrm{MC}}\right]^{-1}\right)$ than in wheat $\left(2.41 \pm 0.04 \%_{\mathrm{RGDW}}\left[\%_{\mathrm{MC}}\right]^{-1} ; p<0.0001\right.$; Fig. 1$)$.

Table 1

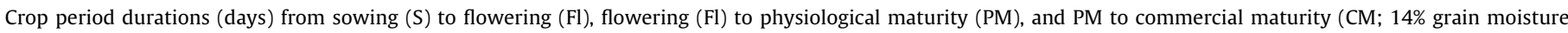

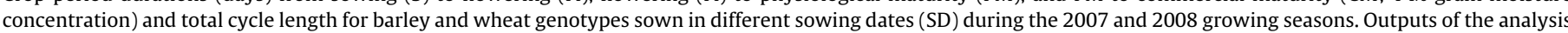
of variance are detailed at the bottom.

\begin{tabular}{|c|c|c|c|c|c|c|c|}
\hline Year & SD & Species & Genotype & S-Fl (days) & Fl-PM (days) & PM-CM (days) & Total (days) \\
\hline \multirow[t]{16}{*}{2007} & \multirow[t]{4}{*}{21 May } & \multirow[t]{2}{*}{ Barley } & Q. Ayelen & 126 & 36 & 15 & 177 \\
\hline & & & Scarlett & 121 & 41 & 13 & 175 \\
\hline & & \multirow[t]{2}{*}{ Wheat } & K. Chaja & 132 & 37 & 15 & 184 \\
\hline & & & Cronox & 131 & 41 & 12 & 184 \\
\hline & \multirow[t]{4}{*}{$5 \mathrm{Jul}$} & \multirow[t]{2}{*}{ Barley } & Q. Ayelen & 97 & 34 & 15 & 146 \\
\hline & & & Scarlett & 97 & 36 & 15 & 148 \\
\hline & & \multirow[t]{2}{*}{ Wheat } & K. Chaja & 103 & 37 & 8 & 148 \\
\hline & & & Cronox & 103 & 39 & 10 & 152 \\
\hline & \multirow[t]{4}{*}{$23 \mathrm{Jul}$} & \multirow[t]{2}{*}{ Barley } & Q. Ayelen & 86 & 26 & 16 & 128 \\
\hline & & & Scarlett & 90 & 24 & 17 & 131 \\
\hline & & \multirow[t]{2}{*}{ Wheat } & K. Chaja & 91 & 26 & 13 & 130 \\
\hline & & & Cronox & 91 & 31 & 11 & 133 \\
\hline & \multirow{4}{*}{17 Aug } & \multirow[t]{2}{*}{ Barley } & Q. Ayelen & 86 & 21 & 13 & 120 \\
\hline & & & Scarlett & 86 & 28 & 5 & 119 \\
\hline & & \multirow[t]{2}{*}{ Wheat } & K. Chaja & 89 & 24 & 9 & 122 \\
\hline & & & Cronox & 89 & 25 & 10 & 124 \\
\hline \multirow[t]{14}{*}{2008} & \multirow[t]{4}{*}{6 Jun } & \multirow[t]{2}{*}{ Barley } & Q. Ayelen & 111 & 33 & 13 & 157 \\
\hline & & & Scarlett & 111 & 35 & 12 & 158 \\
\hline & & \multirow[t]{2}{*}{ Wheat } & K. Chaja & 113 & 39 & 9 & 161 \\
\hline & & & Cronox & 113 & 41 & 9 & 163 \\
\hline & \multirow[t]{10}{*}{13 Aug } & \multirow[t]{2}{*}{ Barley } & Q. Ayelen & 70 & 23 & 8 & 101 \\
\hline & & & Scarlett & 76 & 23 & 13 & 112 \\
\hline & & \multirow[t]{2}{*}{ Wheat } & K. Chaja & 81 & 28 & 8 & 117 \\
\hline & & & Cronox & 82 & 22 & 10 & 114 \\
\hline & & \multirow{2}{*}{\multicolumn{2}{|c|}{$\begin{array}{l}\text { Barley mean } \\
\text { Wheat mean }\end{array}$}} & 96 & 30 & 13 & 139 \\
\hline & & & & 101 & 33 & 10 & 144 \\
\hline & & \multicolumn{2}{|l|}{ SP } & $* * *$ & $* * *$ & $* * *$ & $* * *$ \\
\hline & & \multicolumn{2}{|l|}{ Gen (SP) } & ns & ns & ns & ns \\
\hline & & \multicolumn{2}{|l|}{ SD } & ${ }^{* * *}$ & $* * *$ & $* * *$ & ${ }^{* * *}$ \\
\hline & & \multicolumn{2}{|l|}{$\mathrm{SP} \times \mathrm{SD}$} & $* * *$ & ns & ns & ns \\
\hline
\end{tabular}

${ }^{*} p<0.05$.

${ }^{* *} p<0.01$.

*** $p<0.001$. 
Table 2

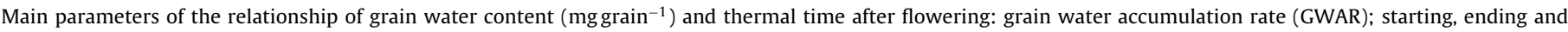

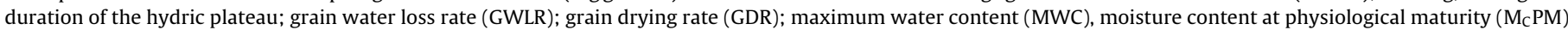
of central grains from barley and wheat (C1) in different sowing dates (SD) during the 2007 and 2008 growing seasons.

\begin{tabular}{|c|c|c|c|c|c|c|c|c|c|c|c|}
\hline \multirow[t]{2}{*}{ Season } & \multirow[t]{2}{*}{ SD } & \multirow[t]{2}{*}{ Species } & \multirow[t]{2}{*}{ Genotype } & \multirow{2}{*}{$\begin{array}{l}\text { GWAR } \\
\left(\mathrm{mg}\left[{ }^{\circ} \mathrm{Cd}\right]^{-1}\right. \\
\left.\operatorname{grain}^{-1}\right)\end{array}$} & \multirow{2}{*}{$\begin{array}{l}\text { MWC } \\
\text { (mg } \\
\text { grain) }\end{array}$} & \multicolumn{3}{|c|}{ Hydric plateau $\left({ }^{\circ} \mathrm{Cd}\right)$} & \multirow{2}{*}{$\begin{array}{l}\text { GWLR } \\
\left(\mathrm{mg}\left[{ }^{\circ} \mathrm{Cd}\right]^{-1}\right. \\
\left.\operatorname{grain}^{-1}\right)\end{array}$} & \multirow[t]{2}{*}{$\mathrm{M}_{\mathrm{C}} \mathrm{PM} \%$} & \multirow{2}{*}{$\begin{array}{l}\text { GDR } \\
\left(\mathrm{g}[\mathrm{kg}]^{-1} \mathrm{~d}^{-1}\right)\end{array}$} \\
\hline & & & & & & Start & End & Duration & & & \\
\hline \multirow{16}{*}{2007} & \multirow{4}{*}{21 May } & \multirow{2}{*}{ Barley } & Q. Ayelen & 0.373 & 46.5 & 202.7 & 388.4 & 185.7 & -0.307 & 48.0 & -28.3 \\
\hline & & & Scarlett & 0.300 & 43.0 & 212.7 & 427.0 & 214.3 & -0.283 & 45.8 & -30.7 \\
\hline & & \multirow[t]{2}{*}{ Wheat } & K. Chaja & 0.180 & 35.0 & 196.3 & 316.4 & 120.1 & -0.137 & 37.8 & -15.9 \\
\hline & & & Cronox & 0.217 & 32.2 & 188.1 & 414.4 & 226.0 & -0.207 & 38.1 & -25.8 \\
\hline & \multirow[t]{4}{*}{$05 \mathrm{Jul}$} & \multirow[t]{2}{*}{ Barley } & Q. Ayelen & 0.200 & 44.2 & 250.6 & 380.9 & 130.3 & -0.145 & 48.4 & -19.8 \\
\hline & & & Scarlett & 0.195 & 40.6 & 230.4 & 372.2 & 141.8 & -0.170 & 47.7 & -25.9 \\
\hline & & \multirow[t]{2}{*}{ Wheat } & K. Chaja & 0.165 & 32.9 & 207.8 & 404.3 & 196.5 & -0.435 & 39.0 & -35.9 \\
\hline & & & Cronox & 0.140 & 28.0 & 203.4 & 372.2 & 191.3 & -0.195 & 35.0 & -27.8 \\
\hline & \multirow[t]{4}{*}{$23 \mathrm{Jul}$} & \multirow[t]{2}{*}{ Barley } & Q. Ayelen & 0.367 & 48.2 & 219.4 & 317.4 & 98.0 & -0.223 & 51.1 & -29.5 \\
\hline & & & Scarlett & 0.260 & 47.1 & 214.9 & 279.6 & 64.6 & -0.167 & 50.5 & -26.3 \\
\hline & & \multirow[t]{2}{*}{ Wheat } & K. Chaja & 0.257 & 33.6 & 164.3 & 225.8 & 61.5 & -0.147 & 40.4 & -25.8 \\
\hline & & & Cronox & 0.357 & 30.7 & 155.4 & 299.7 & 144.3 & -0.120 & 39.2 & -27.3 \\
\hline & \multirow{4}{*}{17 Aug } & \multirow[t]{2}{*}{ Barley } & Q. Ayelen & 0.335 & 48.4 & 153.0 & 303.4 & 150.4 & -0.330 & 52.3 & -31.1 \\
\hline & & & Scarlett & 0.140 & 40.9 & 291.2 & 387.9 & 96.6 & -0.215 & 49.0 & -39.7 \\
\hline & & \multirow[t]{2}{*}{ Wheat } & K. Chaja & 0.190 & 34.8 & 152.0 & 312.9 & 160.9 & -0.310 & 37.4 & -32.3 \\
\hline & & & Cronox & 0.165 & 29.4 & 202.3 & 343.4 & 141.1 & -0.245 & 42.6 & -28.4 \\
\hline \multirow[t]{13}{*}{2008} & \multirow[t]{4}{*}{06 Jun } & \multirow[t]{2}{*}{ Barley } & Q. Ayelen & 0.243 & 44.9 & 235.3 & 322.1 & 86.8 & -0.177 & 48.7 & -26.7 \\
\hline & & & Scarlett & 0.300 & 42.2 & 197.3 & 358.5 & 161.1 & -0.187 & 48.4 & -33.9 \\
\hline & & \multirow[t]{2}{*}{ Wheat } & K. Chaja & 0.190 & 35.9 & 186.8 & 373.9 & 187.0 & -0.233 & 40.7 & -34.2 \\
\hline & & & Cronox & 0.443 & 31.9 & 110.4 & 381.3 & 270.9 & -0.183 & 35.9 & -40.9 \\
\hline & \multirow[t]{9}{*}{13 Aug } & Barley & Q. Ayelen & 0.287 & 38.87 & 154.0 & 366.7 & 212.7 & -0.233 & 48.7 & -30.5 \\
\hline & & & Scarlett & 0.120 & 38.74 & 270.0 & 351.7 & 81.7 & -0.140 & 49.1 & -24.7 \\
\hline & & Wheat & K. Chaja & 0.113 & 26.21 & 180.5 & 442.5 & 262.0 & -0.540 & 37.3 & -34.4 \\
\hline & & & Cronox & 0.110 & 24.22 & 187.8 & 364.8 & 177.0 & -0.267 & 41.3 & -19.9 \\
\hline & & $S p$ & & ns & $* * *$ & $* * *$ & ns & $* *$ & ns & $* * *$ & ns \\
\hline & & $S D$ & & $* *$ & $* * *$ & $*$ & $* * *$ & $* * *$ & ns & $\mathrm{ns}$ & $*$ \\
\hline & & $G(S p)$ & & $*$ & $* * *$ & $* *$ & ns & ns & $*$ & $\mathrm{~ns}$ & ns \\
\hline & & $S p \times S D$ & & ns & ns & ns & $*$ & $*$ & $* *$ & $\mathrm{~ns}$ & $*$ \\
\hline & & $S D \times G$ & & ns & ns & $* * *$ & $* *$ & $* *$ & ns & ns & $*$ \\
\hline
\end{tabular}

${ }^{*} p<0.05$.

** $p<0.01$.

*** $p<0.001$

During early stages of grain filling, grain water accumulation rate significantly differed among sowing dates but did not differ between wheat and barley under different environments (Table 2 ). The range of variation in grain water accumulation rate was from 0.12 to $\left.0.37 \mathrm{mg}^{\circ}{ }^{\circ} \mathrm{Cd}\right]^{-1}$ grain $^{-1}$ and from 0.11 to $0.44 \mathrm{mg}\left[{ }^{\circ} \mathrm{Cd}\right]^{-1}$ grain $^{-1}$ for barley and wheat, respectively. The duration of the hydric plateau was significantly shorter in barley $\left(135^{\circ} \mathrm{Cd}\right)$ than in wheat $\left(180^{\circ} \mathrm{Cd}\right)$, although there was a significant species $\times$ sowing date interaction (Table 2). Differences in the duration of hydric plateau between species were determined by a delayed onset in barley $\left(219^{\circ} \mathrm{Cd}\right)$ respect to wheat $\left(178^{\circ} \mathrm{Cd}\right)$ as differences in the end point of the hydric plateau were not significant (c. $354^{\circ} \mathrm{Cd}$ averaged across sowings for both species). Maximum water content (MWC) reached by the grains was significantly different between species $(p<0.05$; Table 2$)$, being in all cases higher in barley $(43.6 \pm 3.4 \mathrm{mg})$ than in wheat $(31.3 \pm 3.7 \mathrm{mg})$, without interaction with sowing date. Grain water loss rate (GWLR) was similar in both species, although, there was a significant sowing date $\times$ species interaction as species changes the ranking in GWLR depending on the sowing date (Table 2). After physiological maturity, grains continued loosing water at similar rate in wheat and barley $(p>0.1$, Table 2$)$; although, there was a significant species $\times$ sowing date interaction $(p<0.05)$.

When water content data were normalized relative to maximum water content and plotted against the decreasing grain moisture concentration, a unique model fitted all treatment combinations in both species (Fig. 2). Wheat and barley showed a similar relative water accumulation rate per unit of moisture concentration in grains and both species reached the hydric plateau at similar grain moisture concentration (c. 63\%; Fig. 2). However, barley started to lose water with a higher moisture concentration $(p<0.01)$ than wheat (Fig. 2). Conversely, wheat had higher relative water lost rate than barley (Fig. 2).

\subsection{Source-sink manipulation}

When data from source:sink manipulation were analyzed across all environments and grain positions, grains from trimmed spikes were significantly heavier $(p<0.01)$ respect to the control in both species, being the increases, in average, higher in barley (ca. 9\%) than in wheat (ca. 4\%). When each particular position was analyzed although the trend was that grain weight from trimmed spikes were heavier than those of the controls, only some grains evidenced significant differences $(p<0.001)$ between both treatments within each specie (see asterisks in Fig. 3).

\section{Discussion}

An accurate estimation of the precise moment of physiological and especially commercial maturity is important for improving the management of double cropping systems. Calviño et al. (2002) showed that the application of herbicides allowed an advance in wheat harvest without sacrificing too much grain yield and enabling a better soybean performance because of an anticipated planting date. Calviño et al. (2003) reported, in the South East of Buenos Aires Province, yield soybean penalization of $50 \mathrm{Kg} \mathrm{ha}^{-1}$ day $^{-1}$ when sowing dates were delayed after $1 \mathrm{st}$ of January. In this way, knowing the precise moment of physiological and commercial maturity in barley would allow farmers to release the field even earlier by applying herbicides to the winter crop 


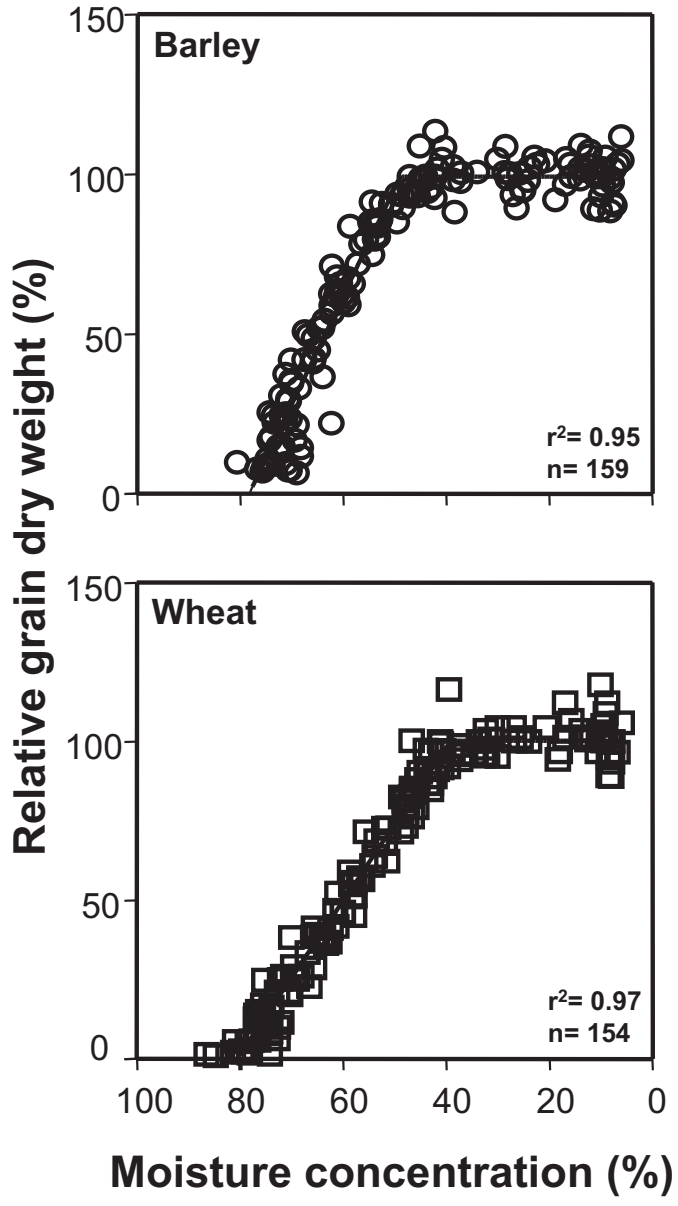

Fig. 1. Relationship between relative grain dry weight (RGDW) and grain moisture concentration $\left(M_{\mathrm{C}}\right)$ in barley and wheat considering all sowing dates carried out during the 2007 and 2008 growing seasons. Lines were fitted using a bi-linear model (see text for details).

without reducing grain yield. As a consequence, double cropping barley/soybean would provide better returns for the system than wheat/soybean. The results of the present study showed that barley was a better predecessor crop, at least in terms of phenology, than wheat for double cropping system due to an earlier release of the field as a consequence of an earlier flowering time rather than by changes in grain-filling or dry down duration after flowering.

Although grains of both species followed the same developmental pattern of water dynamics, they showed important differences in the parameters. We found barley to have significantly higher MWC and $\mathrm{M}_{\mathrm{C}} \mathrm{PM}$ than wheat. The difference in MWC may well explain the commonly reported higher potential grain weight of barley respect to wheat (Dreccer et al., 1997; Abeledo et al., 2002, 2003; Calderini et al., 2000; Ehdaie et al., 2008). The fact that barley reached $\mathrm{PM}$ at higher $M_{C}$ than wheat is relevant in the context of this study as it implies that barley may be sprayed with a desiccant herbicide earlier than wheat, further enlarging the difference between both cereals in field release for sowing soybeans. The $\mathrm{M}_{\mathrm{C}} \mathrm{PM}$ found in the present study for wheat does match pretty well previous reported values (Calderini et al., 2000; Pepler et al., 2006). On the other hand, in the case of barley the results of the present study (48\%) differed from those reported by Bingham et al. (2007b) (40\%). However, differences could be ascribed to the model used to describe the dynamics of dry matter accumulation as a function of the moisture concentration: when we re-analyzed data from Bingham et al. (2007b) fitting an optimization function (data were obtained by using DigitalizeIt V 1.4, Borgmann, 2001), the

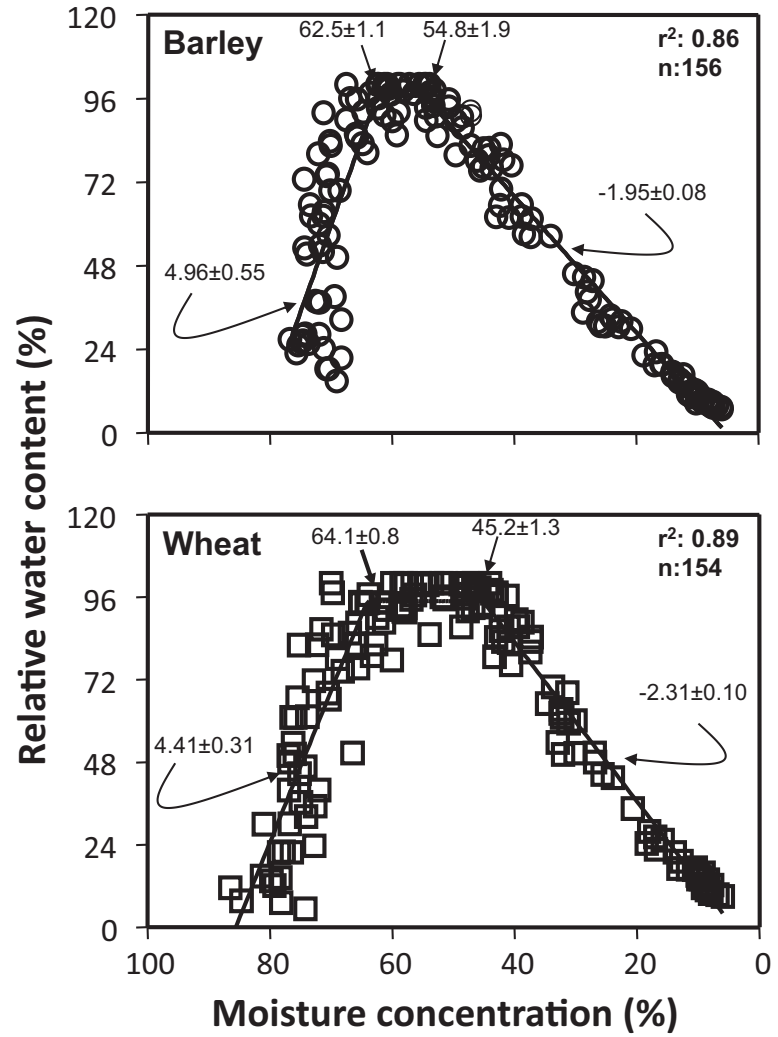

Fig. 2. Dynamics of the relative water content $\left(W_{C}\right)$ as a function of grain moisture concentration $\left(M_{C}\right)$ for barley and wheat during the 2007 and 2008 growing seasons. Data from both species were fitted by a tri-linear model. Parameters of the tri-lineal model (and its corresponding standard errors) are shown in the figure.

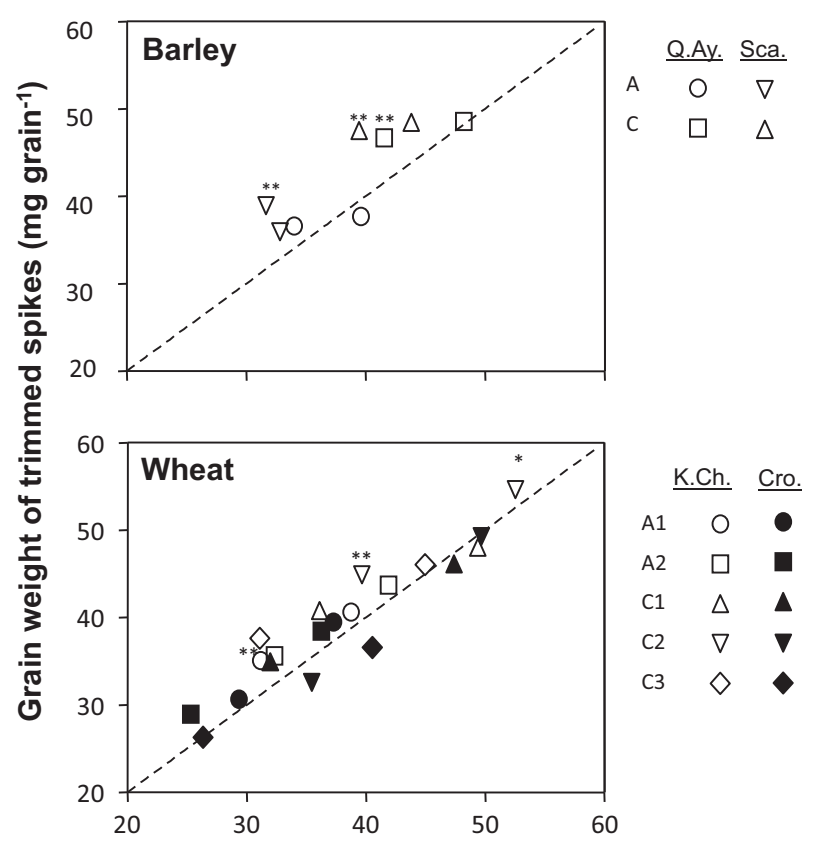

Grain weight of control spikes (mg grain $\left.{ }^{-1}\right)$

Fig. 3. Comparison between control and trimmed spikes treatments for grain weight in wheat and barley. Data from central (circles) and apical (triangles) grain positions correspond to the 2008 growing season. The dotted line indicates the $1: 1$ ratio. 
results showed that barley reached physiological maturity with $48 \%$ moisture concentration in agreement with the results found in the present paper.

Wheat and barley showed differences in grain weight determination when it component was analyzed into the frame of different source:sink ratios during the grain filling period. When assimilate availability per grain was increased by trimming the spikes, barley grains from main shoots showed a slightly higher response in weight than wheat ( $9 \%$ vs $4 \%$ ). Results from this study differed from those reported under dry or relatively dry environments (Josephides, 1993; López-Castañeda and Richards, 1994) and under well watered environments (Bingham et al., 2007a, 2009) where barley was less responsive than wheat.

Grain weight responses associated with increases in source:sink ratio suggest that future increases in yield should probably be accomplished by increases in post-anthesis source strength. In fact the main outcome of breeding in different countries was an improved sink capacity without a corresponding increase in storage reserves or post-anthesis assimilation (source) (Rharrabti et al., 2010; Parry et al., 2011; Foulkes et al., 2011). Thus, if breeding programs continue improving sink capacity, without a corresponding increase in storage reserves or post-anthesis assimilation (source), grain weight responses in both species, but mainly in barley, will continue increasing over the years. The general agreement that at the present grain weight of wheat is scarcely limited by the source (Slafer and Savin, 1994; Borrás et al., 2004) could change assuming that both species will be in the future more and more source limited.

\section{Acknowledgements}

Authors thank Dr. Celina Beltrán for statistical advises, Dr. Brenda L. Gambín and Dr. José L. Rotundo for valuable comments on the previous version, and specially Dr. Gustavo A. Slafer, for valuable comments on the final version of the manuscript. This study was funded by UBACyT G 076 and PICT Raices 1368 projects.

\section{References}

Abeledo, G.L., Calderini, D.F., Slafer, G.A., 2002. Physiological changes associated with genetic improvement of grain yield in barley. In: Slafer, G.A., Molina Cano, J.L., Savin, R., Araus, J.L., Romagnosa, I. (Eds.), Barley: Recent Advances from Molecular Biology to Agronomy of Yield and Quality. Food Product Press, New York, pp. 361-386.

Abeledo, G.L., Calderini, D.F., Slafer, G.A., 2003. Genetic improvement of barley yield potential and its physiological determinants in Argentina (1944-1998). Euphytica $130,325-334$.

Andrade, F.H., 1995. Analysis of growth and yield of maize sunflower and soybean grown at Balcarce, Argentina. Field Crops Res. 41, 1-12.

Bingham, I.J., Blake, J., Foulkes, M.J., Spink, J., 2007a. Is barley in the UK sink limited? I. Post-anthesis radiation interception, radiation-use efficiency and source-sink balance. Field Crops Res. 101, 198-211.

Bingham, I.J., Blake, J., Foulkes, M.J., Spink, J., 2007b. Is barley in the UK sink limited? II. Factors affecting potential grain size. Field Crops Res. 101, 212-220.

Bingham, I.J., Walters, D.R., Foulkes, M.J., Paveley, N.D., 2009. Crop traits and the tolerance of wheat and barley to foliar disease. Ann. Appl. Biol. 154, 159-173.

Borgmann, I., 2001. DigitalizeIt V 1.4. http://www.digitalizeit.de

Borrás, L., Slafer, G.A., Otegui, M.E., 2004. Seed dry weight response to source-sink manipulations in wheat maize and soybean: a quantitative reappraisal. Field Crops Res. 86, 131-146.

Borrás, L., Westgate, M.E., 2006. Predicting maize kernel sink capacity early in development. Field Crops Res. 95, 223-233.
Calderini, D.F., Abeledo, L.G., Slafer, G.A., 2000. Physiological maturity in wheat based on kernel water and dry matter. Agron. J. 92, 895-901.

Calviño, P.A., Studdert, G.A., Abbate, P.E., Andrade, F.H., Redolatti, M., 2002. Use of non-selective herbicides for wheat physiological and harvest maturity acceleration. Field Crops Res. 77, 191-199.

Calviño, P.A., Sadras, V.O., Andrade, F.H., 2003. Quantification of environmental and management effects on the yield of late-sown soybean. Field Crops Res. 83, 67-77.

Cossani, M.C., Slafer, G.A., Savin, R., 2009. Yield and biomass in wheat and barley under a range of conditions in a Mediterranean site. Field Crops Res. 112, 205-213.

Cossani, M.C., Slafer, G.A., Savin, R., 2011. Do barley and wheat (bread and durum) differ in grain weight stability through seasons and water-nitrogen treatments in a Mediterranean location? Field Crops Res. 121, 240-247.

Dreccer, M.F., Grashoff, C., Rabbinge, R., 1997. Source-sink ratio in barley (Hordeum vulgare L.) during grain filling: effects on senescence and grain protein concentration. Field Crops Res. 49, 269-277.

Ehdaie, B., Alloush, G.A., Waines, J.G., 2008. Genotypic variation in linear rate of grain growth and contribution of stem reserves to grain yield in wheat. Field Crops Res. 106, 34-43.

Estrada-Campuzano, G., Slafer, G.A., Miralles, D.J., 2012. Differences in yield biomass and their components between triticale and wheat grown under contrasting water and nitrogen environments. Field Crops Res. 128, 167-169.

Foulkes, J.M., Slafer, G.A., Davies, W.J., Berry, P.M., Sylvester-Bradley, R., Martre, P., Calderini, D.F., Griffiths, S., Reynolds, M.P., 2011. Raising yield potential of wheat. III. Optimizing partitioning to grain while maintaining lodging resistance. J. Exp. Bot. 62, 469-486.

Fischer, R.A., Wood, J.T., 1979. Drought resistance in spring wheat cultivars. III. Yield associations with morpho-physiological traits. Aust. J. Agric. Res. 30, 1001-1020.

Gambín, B.L., Bórras, L., Otegui, M.E., 2007. Kernel water relations and duration of grain-filling in maize temperate hybrids. Field Crops Res. 101, 1-9.

Josephides, C.M., 1993. Analysis of adaptation of barley triticale, durum and bread wheat under Mediterranean conditions. Euphytica 65, 1-8.

Kruk, B.C., Calderini, D.F., Slafer, G.A., 1997. Grain weight in wheat cultivars released from 1920 to 1990 as affected by postanthesis defoliation. J. Agric. Sci. 128, 273-281.

Lingle, S.E., Chevalier, P., 1985. Development of the vascular tissue of the wheat and barley caryopsis as related to the rate and duration of grain filling. Crop Sci. 25, 123-128.

López-Castañeda, C., Richards, R.A., 1994. Variation in températe cereals in rainfed environments. I. Grain yield, biomass and agronomic characteristics. Field Crops Res. 37, 51-62.

Miralles, D.J., Slafer, G.A., 1995. Individual grain weight responses to genetic reduction in culm length in wheat as affected by source-sink manipulations. Field Crops Res. 43, 55-66.

Miralles, D.J., Richards, R.A., 2000. Responses of leaf and tiller emergence and primordium initiation in wheat and barley to interchanged photoperiod. Ann. Bot. 85, 655-663.

Parry, M.A.J., Reynolds, M., Salvucci, M.E., Raines, C., Andralojc, P.J., Zhu, X-G., Price, J.D., Condon, A.G., Furbank, R., 2011. Raising yield potential of wheat. II. Increasing photosynthetic capacity and efficiency. J. Exp. Bot. 62, 453-467.

Pepler, S., Gooding, M.J., Ellis, R.H., 2006. Modeling simultaneously water content of wheat grains. Field Crops Res. 95, 49-63.

Rharrabti, Y., Miralles, D.J., Martos, V., Garcia del Moral, L.F., 2010. Grain weight of durum wheat cultivars released in Italy and Spain during 20th century as affected by source-sink manipulations. Cereal Res. Commun. 38, 134-145.

SAS Institute, 1999. The SAS OnLine Doc v.8. SAS Inst., Cary, NC.

Savin, R., Stone, P.J., Nicolas, M.E., Wardlaw, I.F., 1997. Effects of heat stress and moderately high temperature on grain growth and malting quality of barley. Aust. J. Agric. Res. 48, 615-624.

Schnyder, H., Baum, U., 1992. Growth of the grain of wheat (Triticum aestivum L.). The relationship between water content and dry matter accumulation. Eur. J. Agron. 1, 51-57.

Serrago, R.A., Carretero, R., Bancal, M.O., Miralles, D.J., 2011. Grain weight response to foliar diseases control in wheat (Triticum aestivum L.). Field Crops Res. 120, 352-359.

Slafer, G.A., Savin, R., 1994. Source-sink relationships and grain mass at different positions within the spike in wheat. Field Crops Res. 37, 39-49.

Ugarte, C., Calderini, D.F., Slafer, G.A., 2007. Grain weight and grain number responsiveness to pre-anthesis temperature in wheat, barley and triticale. Field Crops Res. 100, 240-248.

Waddington, S.R., Cartwright, P.M., Wall, P.C., 1983. A quantitative scale of spike initial and pistil development in barley and wheat. Ann. Bot. 51, 119-130. 